\title{
Pengaruh Koneksitas Jaring Terhadap Ketelitian Posisi Pada Survei GPS
}

\author{
TAUFAN AKBAR UTAMA \\ Jurusan Teknik Geodesi, Institut Teknologi Nasional \\ Email :GDtaufan@gmail.com
}

\begin{abstract}
ABSTRAK
Secara teoritis, salah satu faktor yang mempengaruhi ketelitian posisi titik-titik dari survei GPS adalah geometri jaring, yaitu banyaknya jumlah baseline yang terikat ke suatu titik (koneksitas titik). Penelitian ini menganalisis pengaruh banyaknya koneksitas titik dalam suatu jaring terhadap ketelitian posisi yang diperoleh dari hasil pengukuran GPS menggunakan receiverHI-TARGET HD8200XSingle Frequency (L1)dengan format RINEX di 6 titik dengan sebaran titik-titik berada di wilayah Itenas, Gasibu, Cukangkawung, Cikutra, Siliwangi, Antapani dan Jalan Jakarta.Metode pengukuran yang digunakan adalah metode diferensial statik dan diujikan beberapa bentuk desain jaring dengan jumlah koneksitas yang berbeda-beda. Dari hasil hitungan yang diperoleh, jaring GPS dengan koneksitas 2 dan 3 menghasilkan ketelitian posisi horizontal dan vertikal rata-rata $\pm 20 \mathrm{~cm}$ dan $\pm 12 \mathrm{~cm}$,sedangkan untuk koneksitas 4 dan 5 ketelitian posisi horizontal dan vertikal $\pm 9 \mathrm{~cm}$. Penggunaan koneksitas diatas 4 menunjukkan peningkatan ketelitian yang tidak berarti, artinya penggunaan jaring dengan koneksitas 4 sudah optimal.
\end{abstract}

Kata kunci: ketelitian posisi, geometri jaring, koneksitas titik.

\section{ABSTRACT}

Theoretically, one of factor that influenced the points positioning accuracy in GPS surveying is network geometric, which is the number of the baselines that bond to a point (point connectivity). This research analyzed the influence of the number of point connectivity in a single network to the position accuracy that resulted by GPS observation using HI TARGET HD8200X Single Frequency (L1) receiver device with RINEX format. The observation was held using 6 (six) ground points that distributed in different location, those are: ITENAS, Gasibu, Cukangkawung, Cikutra, Siliwangi, Antapani, and Jakarta Street. The method that used in this research was static differential and has been examined in some different network connectivity design. According to the result of this observation, the GPS network with 2 and 3 networks connectivity give the average accuracy of horizontal and vertical position are \pm 20 centimeters and \pm 12 centimeters, while with 4 and 5 networks connectivity is \pm 9 centimeters. The increase of accuracy for network more than 4 connectivities is not significant. So, the use of 4 networks connectivity was the most optimal.

Keywords: position accuracy, network geometry, point connectivity. 


\section{PENDAHULUAN}

Secara umum ketelititan posisi titik-titik yang diperoleh dari survei GPS akan bergantung pada geometri jaring yang digunakan. Desain geometri jaring akan menentukan tingkat ketelitian posisi titik yang diperoleh dari hasil pengukuran. Beberapa faktor yang terkait dengan pembentukan geometri jaring antara lain: jumlah dan distribusi dari titik tetap (titik kontrol), jumlah baseline dalam satu loop, dan koneksitas titik (Abidin, 2000). Koneksitas titik (jumlah baseline yang terikat ke suatu titik) merupakan salah satu faktor dari geometri jaring yang dapat mempengaruhi ketelititan posisi yang diperoleh dari survei GPS.Jumlah koneksitas tersebut harus mempertimbangkan faktor operasional yang berdampak finansial.Secara teori semakin banyak jumlah baseline dalam suatu jaring maka ketelitian posisi yang dihasilkan akan semakin baik (Cahyadi, 2006). Permasalahan yang dapat diajukan adalah bagaimana pengaruh banyaknya koneksitas titik dalam suatu jaring terhadap ketelitian posisi yang diperoleh dari survei GPS dan berapa banyak jumlah koneksitas titik yang optimal dalam suatu jaring sehingga menghasilkan ketelitian yang baik.Tujuan dari penelititan ini adalah menganalisis sampai sejauh mana pengaruh banyaknya koneksitas titik dalam suatu jaring terhadap ketelititan posisi yang diperoleh dari survei GPS.

\section{METODOLOGI PENELITIAN}

Data yang digunakan adalah data hasil pengukuran GPS menggunakan receiverHI-TARGET HD8200X Single Frequency (L1) dengan format RINEX. Metode pengukuran yang digunakan dalam pengambilan data adalah metode diferensial statik dan diujikan beberapa bentuk desain jaring dengan jumlah koneksitas yang berbeda-beda, perancangan desain jaring ini dilakukan untuk mendapatkan bentuk jaring yang benar-benar mewakili dari bentuk-bentuk jaring yang lainnya. Pengukuran dilaksanakan di 6 titik dengan sebaran titiktitik berada di wilayah Itenas, Gasibu, Cukangkawung, Cikutra, Siliwangi, Antapani dan Jalan Jakarta. Data yang diperoleh dari hasil pengukuran kemudian diolah dengan bantuan perangkat lunak TTC2.73untuk memperoleh koordinat beserta ketelitiannya.Tahap selanjutnya adalah dilakukan analisis ketelitian posisi yang dihasilkan pada setiap bentuk geometri jaring dengan jumlah koneksitas titik berbeda-beda tiap jaringnya. Analisis ketelitian berdasarkan ketelitian koordinat yang diwakili oleh harga setengah sumbu panjang dari elips kesalahan absolut dan nilai simpangan baku posisi vertikal. Secara garis besar metode penelitian dapat dilihat pada Gambar 1 berikut. 


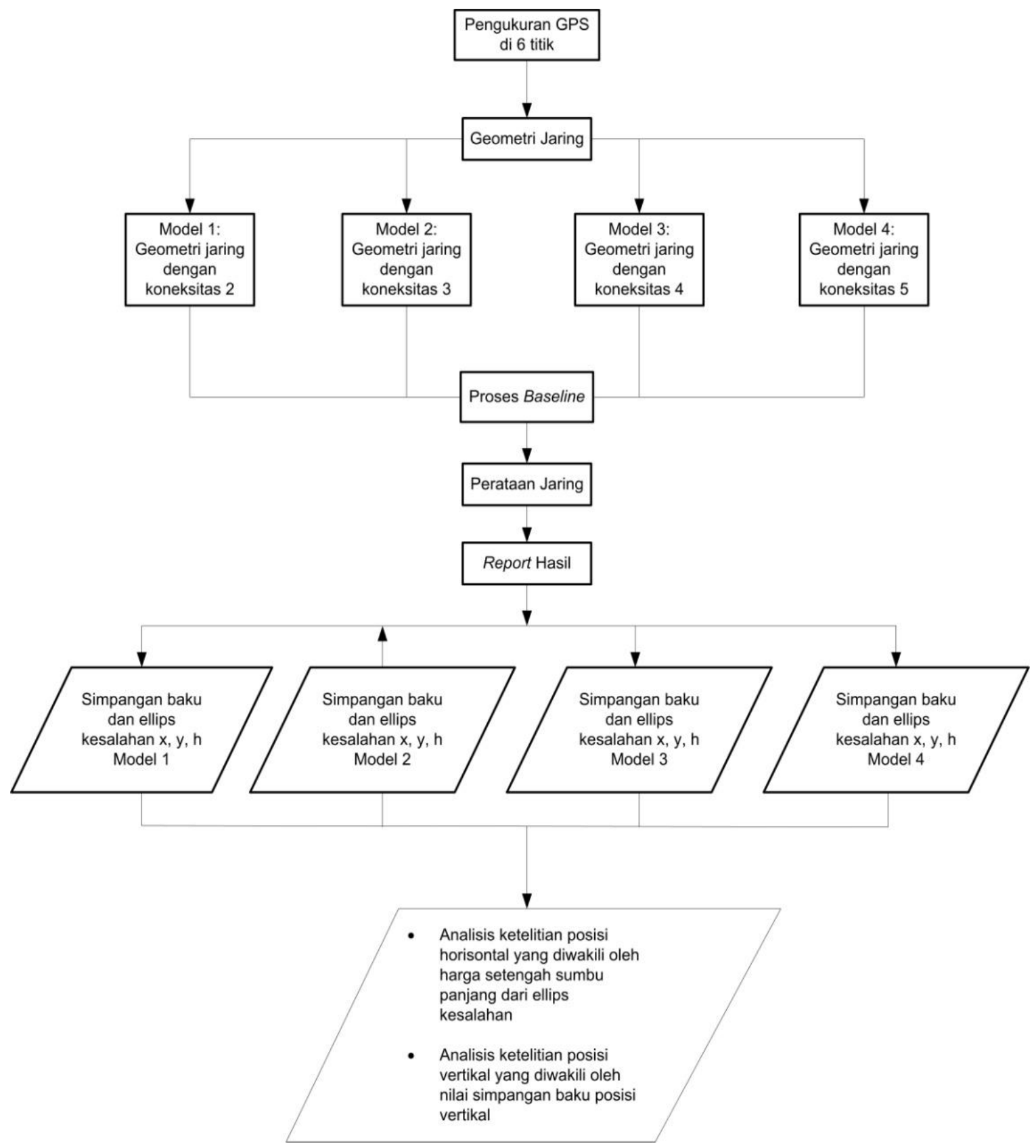

Gambar1. Metodologi Penelitian

\section{HASIL DAN ANALISIS}

Geometri jaring terdiri dari 6 titik pengamatan dengan konfigurasi baseline terdiri dari 4 Model jaringan dengan tingkat koneksitas yang berbeda. Lokasi sebaran titik-titik berada di daerah perumahan Setra Dago (DMG-5030), Jalan Jakarta (CKO-04), Jalan Belitung (SILBPN), Jalan Cukangkawung (BM-97) dan kampus Itenas (ITN-02). Visualisasi Model konfigurasi jaring yang dileliti diGambarkan melalui Gambar 2, 3, 4, dan 5. 


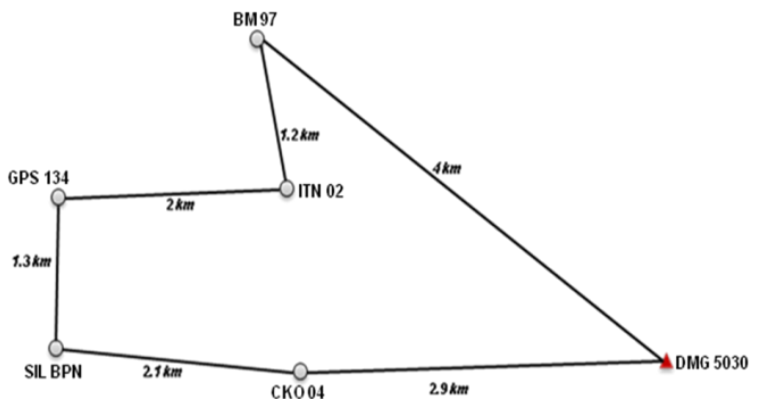

Gambar2. Geometrik Jaring Dengan Koneksitas 2 (Model 1)

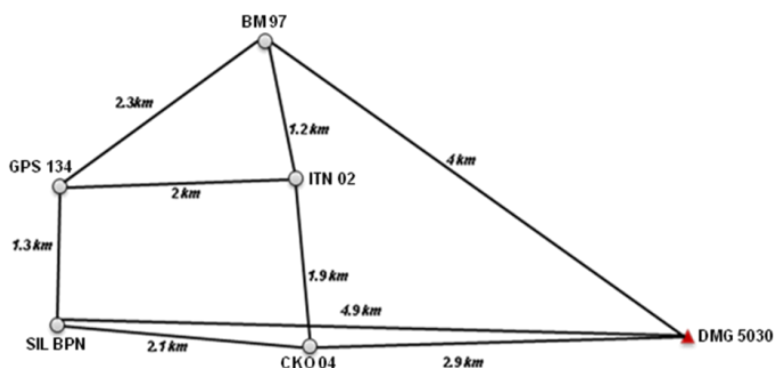

Gambar3. Geometrik Jaring Dengan Koneksitas 3 (Model 2)

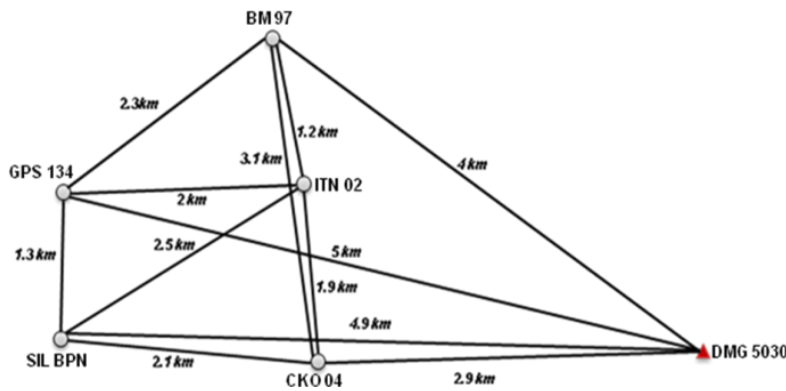

Gambar4. Geometrik Jaring Dengan Koneksitas 4 (Model 3)

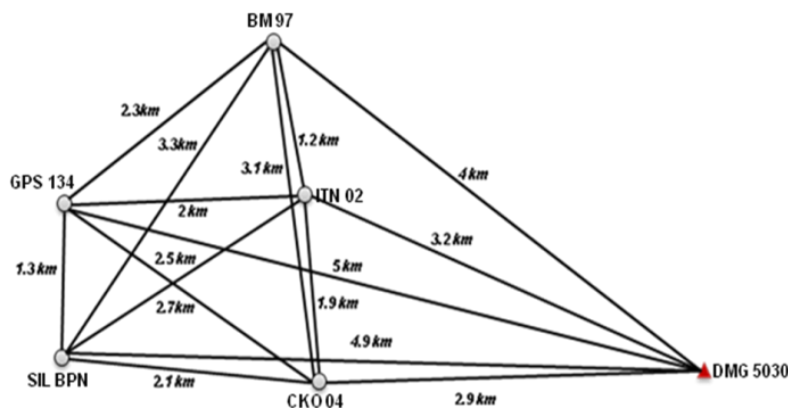

Gambar5. Geometrik Jaring Dengan Koneksitas 5 (Model 4) 
Hasil akhir dari penelitian ini adalah koordinat titik-titik dalam sistem koordinat geodetik $(\mathrm{L}$, B), sistem koordinat proyeksi UTM $(x, y)$ dan tinggi di atas elipsoid $(h)$, simpangan baku $\left(\sigma_{x}\right.$, $\left.\sigma_{y}, \sigma_{h}\right)$, serta nilai elips kesalahan yang diperoleh dari hasil hitungan Model 1, Model 2, Model 3, dan Model 4.

Hasil hitungan Model 1 diperoleh dari hasil pengolahan baselinedan jaringan dengan baselinekoneksitas 2 . Hasil hitungan posisi dengan Model 1 dapat dilihat pada Tabel 1 dan Gambar6.

Tabel 1. Hasil Hitungan Posisi Dan Simpangan Baku Titik Model 1

\begin{tabular}{|c|c|c|c|c|c|c|c|c|c|}
\hline \multirow{3}{*}{ NO } & \multirow{3}{*}{$\begin{array}{l}\text { NAMA } \\
\text { TITIK }\end{array}$} & \multicolumn{5}{|c|}{ KOORDINAT } & \multirow{2}{*}{\multicolumn{3}{|c|}{$\begin{array}{c}\text { SIMPANGAN BAKU } \\
\text { (meter) }\end{array}$}} \\
\hline & & \multicolumn{2}{|c|}{ GEODETIK } & \multicolumn{2}{|c|}{ UTM (meter) } & \multirow{2}{*}{$\begin{array}{c}\begin{array}{c}\text { Tinggi } \\
\text { (meter) }\end{array} \\
\mathbf{h}\end{array}$} & & & \\
\hline & & Lintang (L) & Bujur (B) & $\mathbf{x}$ & $\mathbf{y}$ & & $\sigma_{\mathrm{x}}$ & $\sigma_{y}$ & $\sigma_{\mathrm{h}}$ \\
\hline 1 & DMG 5030 & $6^{\circ} 54^{\prime} 33.526^{\prime \prime}$ & $107^{\circ} 39^{\prime} 46.084^{\prime \prime}$ & 794269.114 & 9235453.210 & 703.511 & - & - & - \\
\hline 3 & GPS 134 & $6^{\circ} 54^{\prime} 00.239^{\prime \prime}$ & $107^{\circ} 37^{\prime} 05.989^{\prime \prime}$ & 789356.842 & 9236503.733 & 746.600 & \pm 0.202 & \pm 0.250 & \pm 0.318 \\
\hline 4 & CKO 04 & $6^{\circ} 54^{\prime} 52.843^{\prime \prime}$ & $107^{\circ} 38^{\prime} 15.083^{\prime \prime}$ & 791470.386 & 9234875.000 & 700.422 & \pm 0.119 & \pm 0.141 & \pm 0.151 \\
\hline 5 & BM 97 & $6^{\circ} 53^{\prime} 12.066^{\prime \prime}$ & $107^{\circ} 38^{\prime} 03.610^{\prime \prime}$ & 791135.056 & 9237974.725 & 760.216 & \pm 0.118 & \pm 0.162 & \pm 0.200 \\
\hline
\end{tabular}

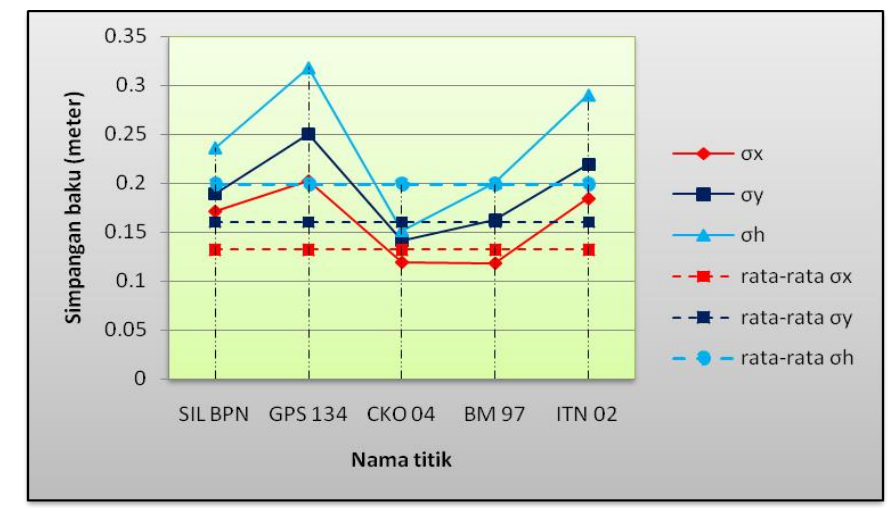

Gambar6. Grafik Simpangan Baku Titik Model 1

Hasil hitungan Model2 diperoleh dari hasil pengolahan baseline dan jaringan dengan baseline koneksitas 3. Hasil hitungan posisi dengan Model2 dapat dilihat pada Tabel2 dan Gambar7. 
Tabel2. Hasil Hitungan Posisi Dan Simpangan Baku Titik Model 2

\begin{tabular}{|c|c|c|c|c|c|c|c|c|c|}
\hline \multirow{3}{*}{ NO } & \multirow{3}{*}{$\begin{array}{l}\text { NAMA } \\
\text { TITIK }\end{array}$} & \multicolumn{5}{|c|}{ KOORDINAT } & \multirow{2}{*}{\multicolumn{3}{|c|}{$\begin{array}{l}\text { SIMPANGAN BAKU } \\
\text { (meter) }\end{array}$}} \\
\hline & & \multicolumn{2}{|c|}{ GEODETIK } & \multicolumn{2}{|c|}{ UTM (meter) } & \multirow{2}{*}{$\begin{array}{c}\begin{array}{c}\text { tinggi } \\
\text { (meter) }\end{array} \\
\mathrm{h}\end{array}$} & & & \\
\hline & & Lintang (L) & Bujur (B) & $\mathbf{x}$ & y & & $\sigma_{\mathrm{x}}$ & $\sigma_{y}$ & $\sigma_{\mathrm{h}}$ \\
\hline 1 & DMG 5030 & 65' $33.526^{\prime \prime}$ & $107^{\circ} 39^{\prime} 46.084^{\prime \prime}$ & 794269.114 & 9235453.210 & 703.511 & - & - & - \\
\hline 2 & SIL BPN & $6^{\circ} 54^{\prime} 41.461 "$ & $107^{\circ} 37^{\prime} 06.588^{\prime \prime}$ & 789368.285 & 9235236.490 & 722.360 & \pm 0.103 & \pm 0.096 & \pm 0.131 \\
\hline 3 & GPS 134 & $6^{\circ} 54^{\prime} 00.237^{\prime \prime}$ & $107^{\circ} 37^{\prime} 06.001^{\prime \prime}$ & 789357.210 & 9236503.768 & 746.522 & \pm 0.134 & \pm 0.113 & \pm 0.165 \\
\hline 4 & CKO 04 & $6^{\circ} 54^{\prime} 52.843^{\prime \prime}$ & $107^{\circ} 38^{\prime} 15.083 "$ & 791470.382 & 9234874.979 & 700.496 & \pm 0.094 & \pm 0.083 & \pm 0.108 \\
\hline 5 & BM 97 & $6^{\circ} 54^{\prime} 12.068^{\prime \prime}$ & $107^{\circ} 38^{\prime} 03.361^{\prime \prime}$ & 791135.070 & 9237974.717 & 760.241 & \pm 0.114 & \pm 0.087 & \pm 0.143 \\
\hline 6 & ITN 02 & $6^{\circ} 53^{\prime} 50.402^{\prime}$ & $107^{\circ} 38^{\prime} 10.152 "$ & 791329.545 & 9236795.205 & 720.998 & \pm 0.127 & \pm 0.105 & \pm 0.157 \\
\hline & & & Rata-rata & & & & \pm 0.095 & \pm 0.081 & \pm 0.117 \\
\hline
\end{tabular}

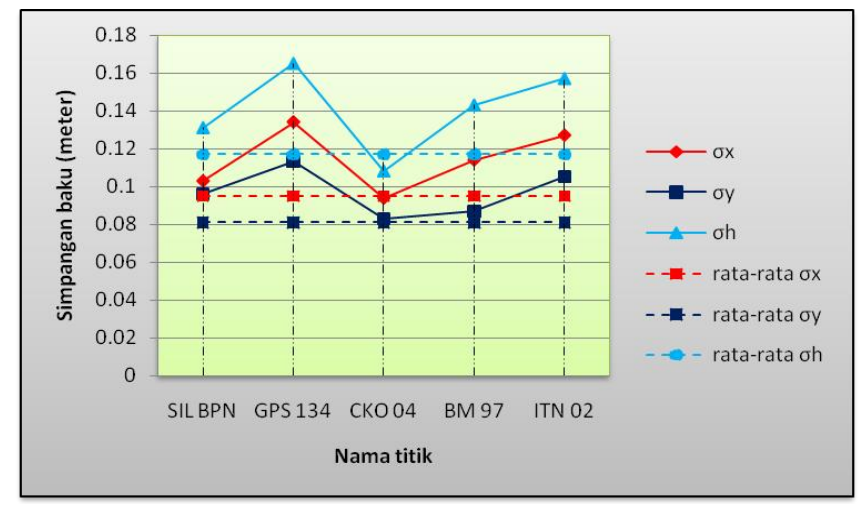

Gambar7. Grafik Simpangan Baku Titik Model2

Hasil hitungan Model3 diperoleh dari hasil pengolahan baselinedan jaringan dengan baselinekoneksitas 4 . Hasil hitungan posisi dengan Model3 dapat dilihat pada Tabel3 dan Gambar8.

Tabel3. Hasil Hitungan Posisi Dan Simpangan Baku Titik Model 3

\begin{tabular}{|c|c|c|c|c|c|c|c|c|c|}
\hline \multirow{3}{*}{ NO } & \multirow{3}{*}{$\begin{array}{l}\text { NAMA } \\
\text { TITIK }\end{array}$} & \multicolumn{5}{|c|}{ KOORDINAT } & \multirow{2}{*}{\multicolumn{3}{|c|}{$\begin{array}{l}\text { SIMPANGAN BAKU } \\
\text { (meter) }\end{array}$}} \\
\hline & & \multicolumn{2}{|c|}{ GEODETIK } & \multicolumn{2}{|c|}{ UTM (meter) } & \multirow{2}{*}{$\begin{array}{c}\begin{array}{c}\text { tinggi } \\
\text { (meter) }\end{array} \\
h\end{array}$} & & & \\
\hline & & Lintang (L) & Bujur (B) & $\mathbf{x}$ & $\mathbf{y}$ & & $\sigma_{x}$ & $\sigma_{y}$ & $\sigma_{\mathrm{h}}$ \\
\hline 1 & DMG 5030 & 6०54' 33.526" & $107^{\circ} 39^{\prime} 46.084^{\prime \prime}$ & 794269.114 & 9235453.210 & 703.511 & - & - & - \\
\hline 2 & SIL BPN & $6^{\circ} 54^{\prime} 41.461 "$ & $107^{\circ} 37^{\prime} 06.587^{\prime \prime}$ & 789368.230 & 9235236.498 & 722.357 & \pm 0.088 & \pm 0.084 & \pm 0.114 \\
\hline 3 & GPS 134 & $6^{\circ} 54^{\prime} 00.237^{\prime \prime}$ & $107^{\circ} 37^{\prime} 06.002^{\prime \prime}$ & 789357.246 & 9236503.754 & 746.448 & \pm 0.091 & \pm 0.080 & \pm 0.112 \\
\hline 4 & CKO 04 & $6^{\circ} 54^{\prime} 52.844 "$ & $107^{\circ} 38^{\prime} 15.083^{\prime \prime}$ & 791470.388 & 9234874.978 & 700.494 & \pm 0.078 & \pm 0.069 & \pm 0.095 \\
\hline 5 & BM 97 & $6^{\circ} 53^{\prime} 12.067^{\prime \prime}$ & $107^{\circ} 38^{\prime} 03.610^{\prime \prime}$ & 791135.074 & 9237974.705 & 760.289 & \pm 0.081 & \pm 0.068 & \pm 0.106 \\
\hline 6 & ITN 02 & $6^{\circ} 53^{\prime} 50.402 "$ & $107^{\circ} 38^{\prime} 10.155^{\prime \prime}$ & 791329.616 & 9236795.206 & 720.954 & \pm 0.098 & \pm 0.086 & \pm 0.123 \\
\hline & & & Rata-rata & & & & \pm 0.073 & \pm 0.065 & \pm 0.092 \\
\hline
\end{tabular}




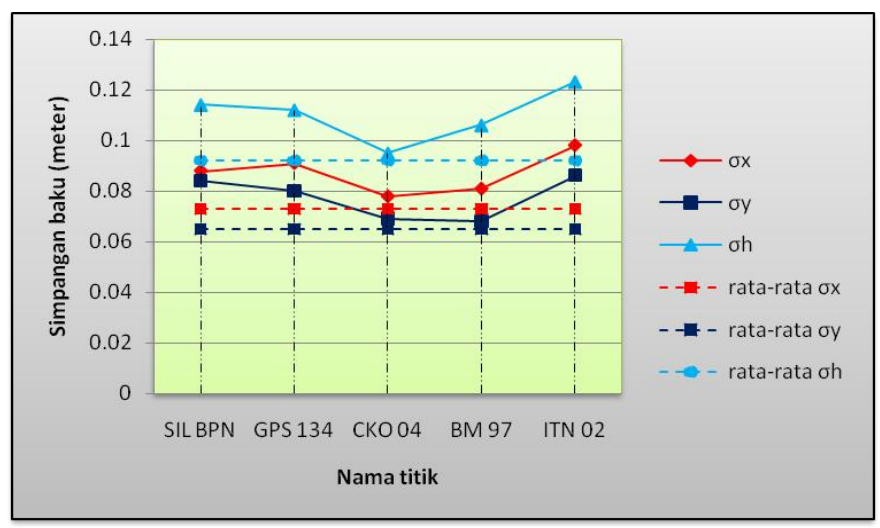

Gambar8. Grafik Simpangan Baku Titik Model3

Hasil hitungan Model4 diperoleh dari hasil pengolahan baselinedan jaringan dengan baselinekoneksitas 5 . Hasil hitungan posisi dengan Model4 dapat dilihat pada Tabel4 dan Gambar9.

Tabel4. Hasil Hitungan Posisi Dan Simpangan Baku Titik Model 4

\begin{tabular}{|c|c|c|c|c|c|c|c|c|c|}
\hline \multirow{3}{*}{ NO } & \multirow{3}{*}{$\begin{array}{l}\text { NAMA } \\
\text { TITIK }\end{array}$} & \multicolumn{5}{|c|}{ KOORDINAT } & \multirow{2}{*}{\multicolumn{3}{|c|}{$\begin{array}{l}\text { SIMPANGAN BAKU } \\
\text { (meter) }\end{array}$}} \\
\hline & & \multicolumn{2}{|c|}{ GEODETIK } & \multicolumn{2}{|c|}{ UTM (meter) } & \multirow{2}{*}{$\begin{array}{c}\begin{array}{c}\text { tinggi } \\
\text { (meter) }\end{array} \\
\mathbf{h}\end{array}$} & & & \\
\hline & & Lintang (L) & Bujur (B) & $\mathbf{x}$ & $\mathbf{y}$ & & $\sigma_{\mathrm{x}}$ & $\sigma_{y}$ & $\sigma_{\mathrm{h}}$ \\
\hline 1 & DMG 5030 & $6^{\circ} 54^{\prime} 33.526 "$ & $107^{\circ} 39^{\prime} 46.084^{\prime \prime}$ & 794269.114 & 9235453.210 & 703.511 & - & - & - \\
\hline 3 & GPS 134 & $6^{\circ} 54^{\prime} 00.237^{\prime \prime}$ & $107^{\circ} 37^{\prime} 06.004^{\prime \prime}$ & 789357.290 & 9236503.777 & 746.521 & \pm 0.084 & \pm 0.073 & \pm 0.100 \\
\hline 4 & CKO 04 & $6^{\circ} 54^{\prime} 52.843^{\prime \prime}$ & $107^{\circ} 38^{\prime} 15.086^{\prime \prime}$ & 791470.457 & 9234875.012 & 700.494 & \pm 0.077 & \pm 0.067 & \pm 0.091 \\
\hline 5 & BM 97 & $6^{\circ} 53^{\prime} 12.066^{\prime \prime}$ & $107^{\circ} 38^{\prime} 03.612^{\prime \prime}$ & 791135.140 & 9237974.727 & 760.329 & \pm 0.083 & \pm 0.069 & \pm 0.105 \\
\hline
\end{tabular}

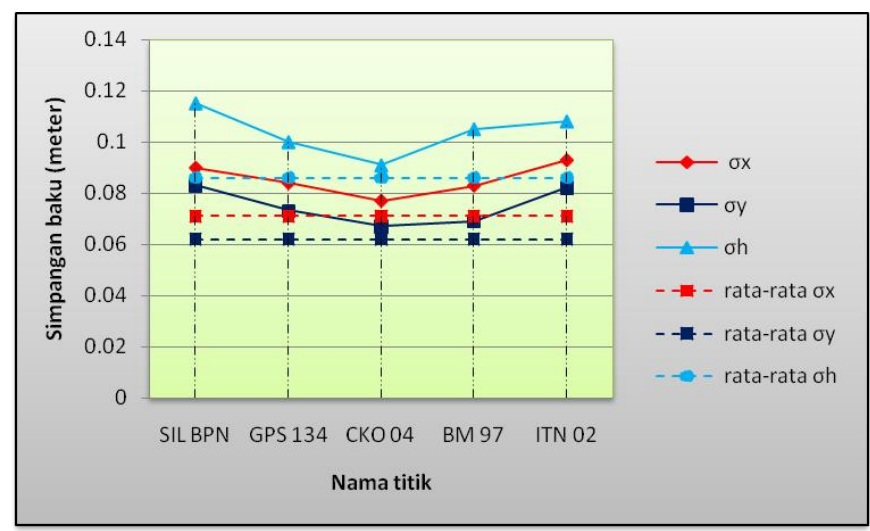

Gambar9. Grafik Simpangan Baku Titik Model4 
Baselineyang diolah dalam penelitian ini merupakan baselinependek $<6 \mathrm{~km}$ sehingga kondisi atmosfer di lokasi pengamatan dapat dianggap sama, dengan demikian pengaruh bias atmosfer di lokasi pengamatan dapat diasumsikan seragam. Data baseline yang diolah adalah databaseline bebas (non trivial), sehingga dari 3 receiver yang aktif pengamatan pada waktu yang sama hanya 2 baseline yang digunakan. Waktu pengamatan untuk setiap baseline dilakukan \pm 90 menit dengan jumlah satelit yang terekam rata-rata sebanyak 9 satelit. Proses pengolahan baselinediawalidengan perbaikan kontinyuitas sinyal dengan melakukan pemotongan sinyal satelit yang terputus-putus saat pengamatan. Pemotong sinyal pada beberapa data pengamatan dilakukan untuk menghilangkan pengaruh noise yang terjadi pada sinyal yang terekam dari masing-masing satelit.Sinyal yang terputus-putus kemungkinan disebabkan karena terganggunya data sinyal dari satelit ke receiver.Pada satelit dengan sinyal yang terekam berkualitas buruk, maka tidak diikutsertakan dalam pengolahan. Secara umum dari keseluruhan data yang digunakan dalam penelitian ini dapat dikatakan cukup valid untuk dilanjutkan proses pengolahan pada perataan baseline.

Ketelitian posisi horizontal yang diwakili oleh harga setengah sumbu panjang $\left(\sigma_{u}\right)$ dari elips kesalahan yang dimiliki oleh masing-masing titik dapat dilihat pada Tabel5 dan Gambar 10.

Tabel 5. Harga Setengah Sumbu Panjang ElipsKesalahan

\begin{tabular}{|c|c|c|c|c|c|}
\hline \multirow{2}{*}{ NO } & \multirow{2}{*}{$\begin{array}{l}\text { NAMA } \\
\text { TITIK }\end{array}$} & \multicolumn{4}{|c|}{$\begin{array}{l}\text { Harga setengah sumbu panjang elips kesalahan } \\
\qquad\left(\sigma_{u}\right)\end{array}$} \\
\hline & & $\begin{array}{r}\text { Model } 1 \\
\text { (meter) }\end{array}$ & $\begin{array}{c}\text { Model } 2 \\
\text { (meter) }\end{array}$ & $\begin{array}{c}\text { Model } 3 \\
\text { (meter) }\end{array}$ & $\begin{array}{c}\text { Model } 4 \\
\text { (meter) }\end{array}$ \\
\hline 1 & DMG 5030 & - & - & - & - \\
\hline 2 & SIL BPN & \pm 0.191 & \pm 0.104 & \pm 0.089 & \pm 0.092 \\
\hline 3 & GPS 134 & \pm 0.254 & \pm 0.135 & \pm 0.092 & \pm 0.084 \\
\hline 4 & CKO 04 & \pm 0.145 & \pm 0.096 & \pm 0.078 & \pm 0.077 \\
\hline 5 & BM 97 & \pm 0.168 & \pm 0.117 & \pm 0.083 & \pm 0.084 \\
\hline 6 & ITN 02 & \pm 0.227 & \pm 0.127 & \pm 0.098 & \pm 0.094 \\
\hline \multicolumn{2}{|c|}{ Rata-rata } & \pm 0.197 & \pm 0.116 & \pm 0.088 & \pm 0.086 \\
\hline
\end{tabular}

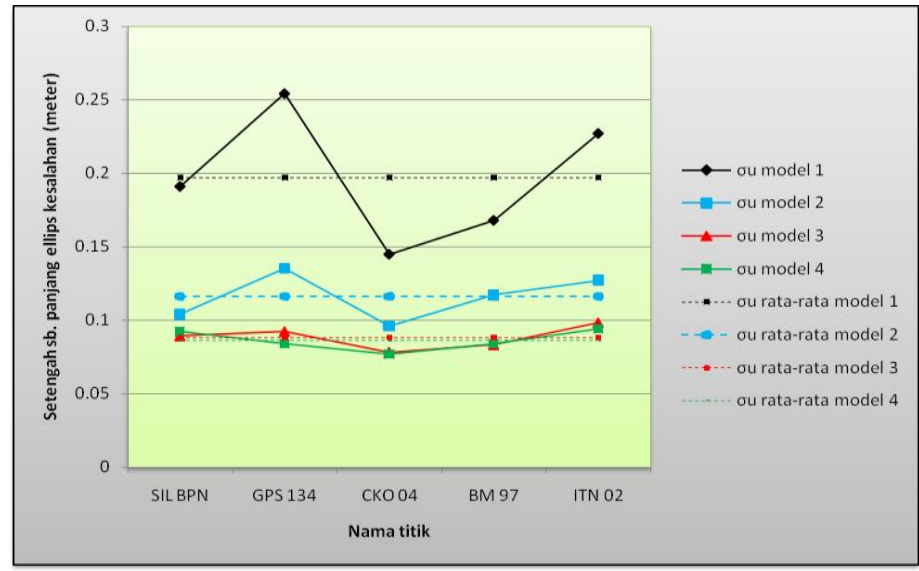

Gambar10. Perbandingan Harga Setengah Sumbu Panjang Elips Kesalahan 
Berdasarkan Tabel5 dan grafik yang dtunjukkan pada Gambar9 dapat dianalisis hal-hal terkait sebagai berikut.Ketelitian posisi titik horizontal yang ditunjukkan pada Model 1 mempunyai harga yang paling jelek dan mempunyai nilai yang bervariatif dibandingkan dengan ketiga model hitungan yang lain (Model 2, 3, dan 4), ketelitian rata-rata posisi titik horizontal yang ditunjukkan pada Model 1 dan Model 2 masing-masing berkisar sekitar \pm 20 $\mathrm{cm}$ dan $\pm 12 \mathrm{~cm}$, ketelitian rata-rata posisi titik horizontal yang ditunjukkan pada Model 3 dan Model 4 cenderung memiliki nilai yang homogen berkisar sekitar $\pm 9 \mathrm{~cm}$.

Berdasarkan analisis di atas dapat disimpulkan sebagai berikut.Tingkat ketelitian posisi titiktitik horizontal berdasarkan harga setengah sumbu panjang dari elips kesalahan pada jaring GPS sangat tergantung pada tingkat koneksitas titik, jaring GPS yang terdiri dari baseline yang diukur dengan receiver satu frekuensi dengan koneksitas 2 mempunyai ketelitian ratarata $\pm 20 \mathrm{~cm}$, jaring GPS yang terdiri dari baseline yang diukur dengan receiver satu frekuensi dengan koneksitas 3 mempunyai ketelitian rata-rata $\pm 12 \mathrm{~cm}$, jaring GPS yang terdiri dari baseline yang diukur dengan receiver satu frekuensi dengan koneksitas 4 dan 5 mempunyai ketelitian rata-rata $\pm 9 \mathrm{~cm}$, peningkatan nilai koneksitas baselinedi atas empat menunjukkan peningkatan ketelitian yang tidak terlalu berarti.

Ketelitian posisi vertikal diwakili oleh nilai simpangan bakunya $\left(\sigma_{h}\right)$.Rekapitulasi besarnya simpangan baku rata-rata posisi vertikal untuk masing-masing hitungan ditampilkan pada Tabel6 dan Gambar 11.

Tabel 6. Perbandingan Simpangan Baku Rata-Rata Posisi VertikalModel 1, 2, 3 dan 4

\begin{tabular}{|c|c|c|c|c|c|}
\hline \multirow{2}{*}{ No } & \multirow{2}{*}{ Nama titik } & \multicolumn{4}{|c|}{ Simpangan baku posisi vertikal (meter) } \\
\cline { 3 - 6 } & & Model 1 & Model 2 & Model 3 & Model 4 \\
\cline { 3 - 6 } & & $\sigma_{\mathrm{h}}$ & $\sigma_{\mathrm{h}}$ & $\sigma_{\mathrm{h}}$ & $\sigma_{\mathrm{h}}$ \\
\hline 1 & DMG 5030 & - & - & - & - \\
\hline 2 & SIL BPN & \pm 0.236 & \pm 0.131 & \pm 0.114 & \pm 0.115 \\
\hline 3 & GPS 134 & \pm 0.318 & \pm 0.165 & \pm 0.112 & \pm 0.100 \\
\hline 4 & CKO 04 & \pm 0.151 & \pm 0.108 & \pm 0.095 & \pm 0.091 \\
\hline 5 & BM 97 & \pm 0.200 & \pm 0.143 & \pm 0.106 & \pm 0.105 \\
\hline 6 & ITN 02 & \pm 0.290 & \pm 0.157 & \pm 0.123 & \pm 0.108 \\
\hline \multicolumn{7}{|c|}{ Rata-rata } & $\mathbf{\pm 0 . 1 9 9}$ & $\mathbf{\pm 0 . 1 1 7}$ & $\mathbf{\pm 0 . 0 9 2}$ & $\mathbf{0 0 . 0 8 6}$ \\
\hline
\end{tabular}

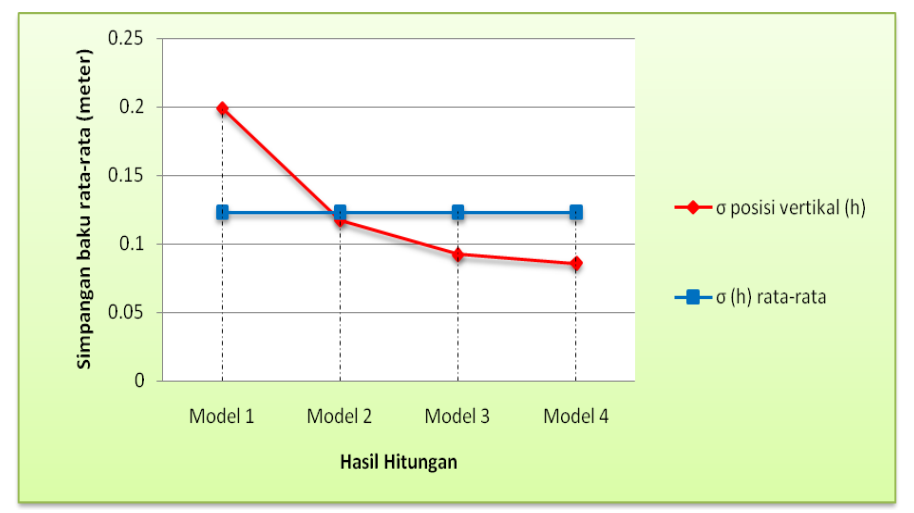

Gambar 11. Grafik Perbandingan Simpangan Baku (h) Model 1, 2, 3, dan 4 
Berdasarkan Tabel 6 dan grafik yang ditunjukkan pada Gambar11, dapat dianalisis hal-hal terkait sebagai berikut.Ketelitian posisi titik vertikal yang ditunjukkan pada Model 1 mempunyai harga yang paling jelek dibandingkan dengan ketiga model hitungan yang lain (Model 2, 3, dan 4), ketelitian rata-rata posisi titik vertikal yang ditunjukkan pada Model 1 dan Model 2 masing-masing berkisar sekitar $\pm 20 \mathrm{~cm}$ dan $\pm 12 \mathrm{~cm}$, ketelitian rata-rata posisi titik vertikal yang ditunjukkan pada Model 3 dan Model 4 berkisar sekitar $\pm 9 \mathrm{~cm}$, ketelitian rata-rata posisi titik vertikal dari Model hitungan seperti yang ditunjukkan oleh grafik pada Gambar11 cenderung meningkat secara ekstrim, terutama dari Model 1 ke Model 2 dan ke Model 3. Sedangkan dari Model 3 ke Model 4 cenderung memiliki nilai yang konstan.

Berdasarkan analisis di atas dapat disimpulkan sebagai berikut.Tingkat ketelitian posisi vertikal titik-titik pada jaring GPS sangat tergantung pada tingkat koneksitas titik, jaring GPS yang terdiri dari baseline yang diukur dengan receiver satu frekuensi dengan koneksitas 2 mempunyai ketelitian rata-rata $\pm 20 \mathrm{~cm}$, jaring GPS yang terdiri dari baselineyang diukur dengan receiver satu frekuensi dengan koneksitas 3 mempunyai ketelitian rata-rata \pm 12 $\mathrm{cm}$, jaring GPS yang terdiri dari baseline yang diukur dengan receiver satu frekuensi dengan koneksitas 4 dan 5 mempunyai ketelitian rata-rata $\pm 9 \mathrm{~cm}$, peningkatan nilai koneksitas baseline diatas 4 menunjukkan peningkatan ketelitian yang tidak terlalu berarti.

\section{KESIMPULAN}

Berdasarkan hasil analisis dari data penelitian hasil survei GPS satu frekuensi (L1), dapat disimpulkan bahwa tingkat koneksitas baseline pada survei GPS berpengaruh terhadap ketelitian posisi yang dihasilkan. Ketelitian posisi horizontal dan vertikal titik-titik jaring GPS yang dihasilkan dengan koneksitas baseline 2 dan 3,masing-masing adalah $\pm 20 \mathrm{~cm}$ dan \pm $12 \mathrm{~cm}$, sedangkan ketelitian posisi horizontal dan vertikal titik-titik jaring GPS dengan koneksitas baseline4 dan 5mempunyai nilai yang konstan yaitu $\pm 9 \mathrm{~cm}$.Peningkatan nilai koneksitas baselinedi atas 4, ketelitian posisi titik tidak meningkat secara berarti.

\section{UCAPAN TERIMA KASIH}

Rasa terima kasih yang sedalam-dalamnya disampaikan kepada PT. Mysurv Penta Buana yang telah menyediakan peralatan dan kepada Saudara Fernando, Rendy, Iyan, Dio, Enur, Damdam yang telah membantu selama pengukuran berlangsung.

\section{DAFTAR PUSTAKA}

Abidin, H.Z., Mugiarto, F.J. (2000). Pengaruh Geometri Jaringan Terhadap Ketelitian Survei GPS. Dipetik June 15, 2012, dari: Jurnal Surveying Dan Geodesi, Vol. X, No.1: http://www.gd.itb.ac.id/jurnal/V10-1-1a.pdf

Cahyadi, M. Nur. (2006) Analisis Kualitas Jaring Pada Pengamatan GPS. Dipetik May 08, 2012, dari: Jurnal Teknik Geomatika-ITS: http://digilab.its.ac.id 